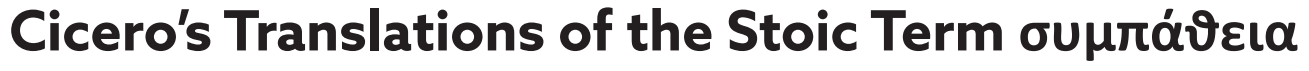 into Latin
}

\section{Peter Fraňo}

(University of Ss. Cyril and Methodius in Trnava)

\begin{abstract}

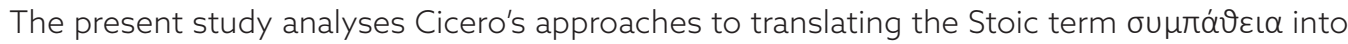
Latin. In his treatise On Fate, the Roman author differentiates two types of situation in which Stoic sympathy functions. In the scientific sense, the word sympathy refers to mutual connections between physical phenomena, such as the connections between the phases of the moon and the alternating tides. In the divinatory sense, sympathy acts in the connection between a prophecy and its fulfilment, such as between the flight of birds and the start of a war. In Cicero's view, only the scientific sense of sympathy should be accepted. For this reason, in

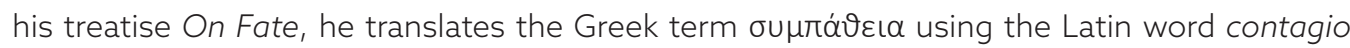
(Cic. Fat. 3, 5-6), since the verb tango means "to make or come into physical contact with". In contrast, he does not accept that sympathy acts in a divinatory sense, explaining the connection between a prophecy and its fulfilment as the result of chance.
\end{abstract}

\section{Keywords}

Stoic sympathy; Cicero; translation; On Fate; divination; fate; causality 


\section{Introduction ${ }^{1}$}

Cicero was driven to create a Latin lexicon of philosophical terms ${ }^{2}$ because he was convinced, from both a historical and a patriotic perspective, that many parts of Roman culture was sufficiently sophisticated. Although Cicero recognised the pre-eminence of the Greeks in science and philosophy, he also believed that Greek society had contributed all it could to culture and civilization, and that a new Latin culture should replace it, taking the glory of Greek learning and transferring it to Rome (laudem iam languenti Graeciae eripiant et transferant in hanc urbem) (Cic. Tusc. 2, 2, 5). In the field of philosophy, Cicero would implement this cultural agenda by writing original philosophical treatises and by translating Greek texts into Latin.

This project necessitated the creation of a new Latin lexicon of philosophical terms. In this regard, Cicero realised that he was stepping out into somewhat uncharted territory; in the Roman cultural context, no one had yet attempted to address this issue. ${ }^{3}$ For this reason, he had to create some basic rules to follow when coining and translating Latin technical terms. One of his main principles stated that Latin expressions should be prioritised over Greek ones. Thus, only in exceptional circumstances did Cicero leave a term in Greek or in Greek transliteration.

Cicero detailed his methodological approach to translation in the third book of his treatise On Ends (Cic. Fin. 3, 4, 15). Jonathan Powell differentiated three basic approaches to translating Greek philosophical terms into Latin, as follows: "First, the use of a more ordinary, less technical word than the Greek equivalent. Second, the use of a number of words to translate a single Greek word. Third, the direct borrowing of the Greek word itself”. ${ }^{4}$

Another of Cicero's principles stated that a newly-translated expression should correspond with the novel circumstances in which it would be applied. If Cicero believed that a term had been used incorrectly based on his own philosophical convictions, he would translate it in a way that corresponded with the new meaning. For example, Cicero often criticised the philosophical lexicon of the Stoics (see Cic. Fin. 3, 1, 3), who he thought introduced new concepts such as would legitimate new terminology. For this reason, Cicero translated the Greek term бó to refer to a certain approach to argumentation, into the Latin word laqueus (see Cic. Tusc. 5, 27, 76; de Orat. 1, 10, 43; Fat. 4, 7), which literally means "a loop of rope tied with a running knot" or "the snare of a lasso for catching wild animals". With such a term, Cicero gave the word a more sarcastic undertone, thus emphasizing his own sceptical

1 The study was supported by a grant from the project APVV-17-0128 and FPPV-15-2020.

2 For more on Cicero's formulation of Latin philosophical terms, see Hartung (1970), Powell (2002), Baltussen (2011) and Glucker (2012).

3 Lucretius was the first Latin writer known to translate Epicurean ideas into Latin. For more on Lucretius's translation, see Sedley (2004: pp. 35-61); Garani (2007).

4 Powell (2002: p. 292).

$5 \quad$ Glare (1968: p. 1002). 
philosophical convictions, which led him to believe that the main aim of sophisms was to catch an opponent in an argumentative trap. ${ }^{6}$

\section{Stoic sympathy}

In this paper, we examine how Cicero applied these rules to his translation of the Greek

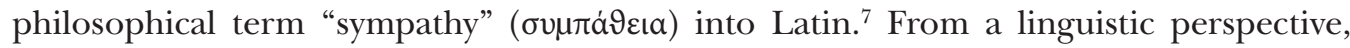
this word is formed from a combination of the Greek prefix oúv (meaning "in company

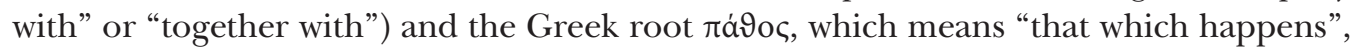
"emotion, passion", or "state, condition". 8

In his own works, Cicero only discusses this term in the context of Stoicism, although the expression is also found in the works of Plato, Aristotle, and the Epicureans. ${ }^{9}$ The

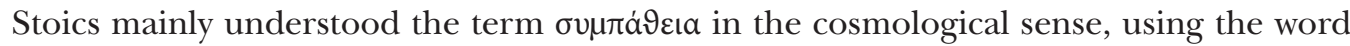
to express a certain unifying dynamic principle by which all elements of the universe were harmoniously arranged into a single coherent system. Sympathy was related to "the active" principle ( (SVF I, 85). "The active" principle, in the form of "breath" ( $\pi v \varepsilon \tilde{u} \mu \alpha)$ at various "degrees

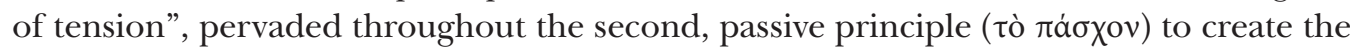
diverse elements of the universe. ${ }^{11}$

Because of sympathy, the universe constituted a unified, living and breathing organism in which each individual component influenced all others. For this reason, sympathy was mentioned mainly in discussions about how heavenly phenomena, such as the phases of the moon, affected the arrival and departure of sea creatures or the alternating high and low tides (SVF II, 1013). Because of this physical action, sympathy was often connected with causality, fate, and divination.

In Stoic philosophy, fate came to be interpreted, at its most basic level, through the lens of causal theory. In the treatise On Divination, Cicero defined fate as follows: "Now

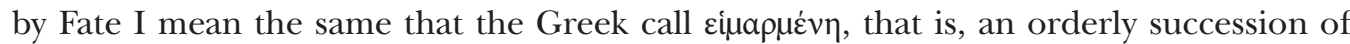
causes wherein cause is linked to cause and each cause of itself produces an effect. That is an immortal truth having its source in all eternity. Therefore, nothing has happened which was not bound to happen, and, likewise, nothing is going to happen which will not find in nature every efficient cause of its happening. Consequently, we know that

6 In a similar way, Cicero shifts the meaning of words to reflect new concepts when translating Greek texts into Latin. For example, when translating part of Plato's Republic in the treatise On the Republic. See Gregory (1991).

7 The term "sympathy" can be perceived in a philosophical or medical sense. For more on medical "sympathy", see Holmes (2012; 2014).

$8 \quad$ Liddell \& Scott \& Jones (1996: pp. 1690, 1285).

9 See Brouwer (2015: pp. 16-20).

10 "The active principle" had other names, such as "god", "Zeus", "intellect", "fate", "providence", and "law" (D. L. 7, 136-139; SVF III, 314).

11 For more on Stoic physics, see Sellars (2006: pp. 81-106); White (2003: pp. 124-152). 
Fate is that which is called, not ignorantly, but scientifically, 'the eternal cause of things, the wherefore of things past, of things present, and of things to come"' (Fatum autem id

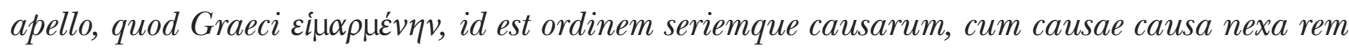
ex se gignat. Ea est ex omni aeternitate fluens veritas sempiterna. Quod cum ita sit, nihil est factum, quod non futurum fuerit, eodemque modo nihil est futurum, cuius non causas id ipsum, efficientes natura contineat. Ex quo intellegitur, ut fatum sit non id, quod superstitiose, sed id, quod physice dicitur, causa aeterna rerum, cur et ea, quae praeterierunt, facta sint et, quae instant, fiant et, quae sequuntur, futura sint) (Cic. Div. 1, 55, 125-126). ${ }^{12}$ Based on this definition, it

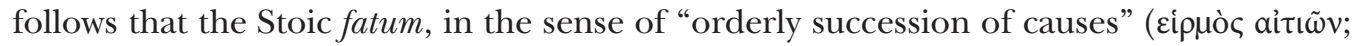
ordo seriesque causarum), was an integral part of the physical universe that could not be avoided under any circumstances. ${ }^{13}$

Furthermore, Cicero's testimony implies that the term fatum referred to a physical phenomenon on which time depends that allowed future events to be predicted based on retrograde extrapolation of causes. ${ }^{14}$ Indeed, the Stoics compared the timeline of the future to "the unwinding of a cable" (rudentis explicatio), whereby nothing new arose and only prior events repeatedly unfolded. Causes of this nature left certain "signs" (signa) and "tokens" (notas), so those who had learned to correctly interpret the signs could use them to predict the future (Cic. Div. 1, 56, 127). ${ }^{15}$

This interpretation of physics led to some important conclusions with regards to predicting the future. Fate could now be conceived as a part of the physical universe that could be understood based on empirical experience. One simply had to recognise the signs, which were connected in space and time by sympathy. Therefore, fate, sympathy, and divination are mutually connected and interdependent. Specifically, divination cannot exist without fate, which in turn depends on $\sigma \nu \mu \pi \alpha \dot{\vartheta} \varepsilon\llcorner a$ to ensure the relationship between individua and the whole. ${ }^{16}$

\section{Sympathy in Cicero's treatises}

Based on the Stoic theory of causes, the term sympathy could be used both to clarify the connections between physical phenomena and to defend the legitimacy of divination. Cicero attempted to incorporate both of these frameworks - the scientific and the divinatory - into his Latin translation of the term. The following table details all the Latin phrases that Cicero used in his treatises when dealing with the term Stoic sympathy:

12 Transl. Falconer (1923: p. 361).

13 Karfík (1998: p. 61).

14 See Schallenberg (2008: pp. 10-13); Sorabji (1983).

15 Transl. Falconer (1923: p. 363). For stoic belief in divination and the controversy it sparked, see Hankinson (1988); Long (2006: pp. 128-153). For divination and magic in the Hellenistic age, see Kalaš \& Škvrnda (2018a; 2018b).

16 See SVF II, 939; Alex. Aphr. Fat. 30, 200, 12; 31, 201, 32; Cic. Div. 1, 56, 127. 


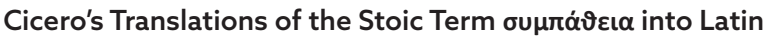

\begin{tabular}{|c|c|c|}
\hline Latin phrases & Latin context & Latin source \\
\hline $\begin{array}{l}\text { consentiens, conspirans, } \\
\text { cognatio continuata }\end{array}$ & $\begin{array}{l}\text { tanta rerum consentiens, conspirans, } \\
\text { continuata cognatio }\end{array}$ & Nat. deor. 2, 7, 19 \\
\hline convenientia, consensus & $\begin{array}{c}\text { totius mundi convenientiam } \\
\text { consensumque }\end{array}$ & Nat. deor. 3, 7, 18 \\
\hline convenientia, consensus & de convenientia consensuque naturae & Nat. deor. 3, 11, 28 \\
\hline cognatio continuata & quasi cognatione continuatam conspirare & Nat. deor. 3, 11, 28 \\
\hline consensus & 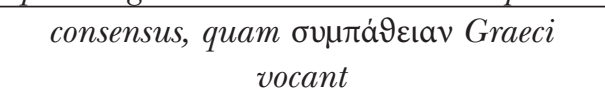 & Nat. deor. 3, 11, 28 \\
\hline cognatio & $\begin{array}{c}\text { rerum autem natura quam cognationem } \\
\text { habent }\end{array}$ & Div. 2, 14, 33 \\
\hline consensus et continens & uno consensu iuncta sit et continens & Div. 2, 14, 33 \\
\hline coniuncta & coniuncta mundo & Div. 2, 14, 33 \\
\hline contagio & in natura rerum contagio & Div. 2, 14, 33 \\
\hline cognatio & rerum cognatio naturalis & Div. 2, 14, 34 \\
\hline $\begin{array}{l}\text { coniunctio, concentus, } \\
\text { consensus }\end{array}$ & 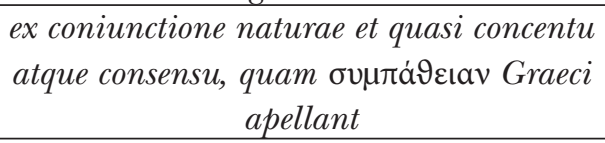 & Div. 2, 14, 34 \\
\hline convenientia & convenientiam naturae & Div. 2, 15, 34 \\
\hline conveniens & velit convenientem hostiam rebus & Div. 2, 15, 35 \\
\hline conveniens et coniunctio & $\begin{array}{c}\text { conveniente et coniunctione naturae, } \\
\text { quam vocant } \sigma v \mu \pi \dot{\jmath} \varepsilon\llcorner\alpha v\end{array}$ & Div. 2, 60, 124 \\
\hline continuatio coniunctioque & 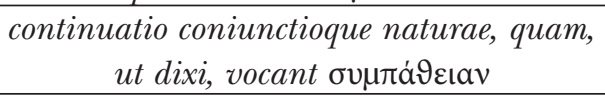 & Div. 2, 69, 142 \\
\hline sympathia & Video sympathiam & Div. 2, 69, 143 \\
\hline consensus & vim consensumque naturae & Div. 2, 70, 144 \\
\hline contagio & naturae contagio & Fat. 3, 5 \\
\hline contagio & de ipsa contagione rerum & Fat. 4,7 \\
\hline
\end{tabular}

Cicero dealt with the issue of $\pi \varepsilon \rho \mathrm{i} \sigma u \mu \pi a \vartheta c i a c$ in three consecutive treatises: On the Nature of the Gods, On Divination, and On Fate. Only in four instances did he explicitly

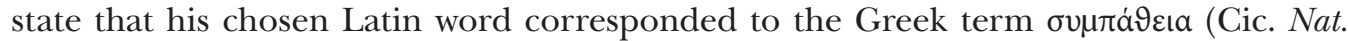
deor. 3, 11, 28; Div. 2, 14, 34; 2, 60, 124; 2, 69, 142). In all other cases, the context of the passage makes it clear that Cicero was referring to the term sympathy. As shown in the table, the Roman philosopher used a broad range of terms to translate the concept, but in almost all cases, he replaced the Greek prefix oúv from the word $\sigma 0 \mu \pi \dot{q} \vartheta \varepsilon ı$ with its Latin equivalent con-, meaning "collocation" or "connection". ${ }^{17}$

While the meaning of the prefix is identical in both languages, the root words differ. Cicero must have realised that he could not interpret the term ná9os verbum e verbo when its main philosophical meaning varied so widely. In the Stoic understanding, the Greek

17 Glare (1968: p. 383). 
word $\pi \dot{\alpha} \vartheta$ oc has mostly negative connotations, ${ }^{18}$ referring above all to "strong emotions" or "passions" 19 - mental processes that are removed from the reason and therefore violate the rational nature of man..$^{20}$ Therefore, Cicero translated the term into Latin using the very emotionally loaded term perturbatio (Cic. Fin. 3, 10, 35), meaning "physical disturbance", "confusion", "disorder", which derives from the Latin word perturbo ("throw into confusion", "disrupt", "disorganise", "arouse"). ${ }^{21}$ For this reason, when translating the term $\sigma u \mu \pi \dot{\alpha} 9 \varepsilon i \alpha$, he chooses more neutral Latin words that shift the negative emotional aspects into the background $($ consensus $=$ con + sensus; conspiro $=$ con + spiro; contagio $=$ con + tango $;$ cognatio $=c o+$ gnascor $;$ convenientia $=c o n+$ venio $;$ coniunctio $=$ con + iungo $)$. Moreover, in almost all cases, Cicero tended to emphasise the physical when dealing with

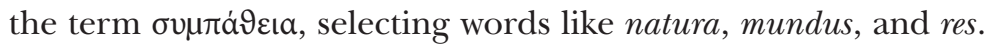

With regards to the particular methods Cicero used to translate philosophical terms, which are detailed above, the oldest treatise On the Nature of the Gods still tended to use several Latin words to translate a single Greek word (see the table). However, in the treatise On Divination, Cicero gradually began to use a single Latin equivalent to express the Greek term sympathy, although he was not yet consistent, alternating the words cognatio, coniuncta, contagio, cognatio, convenientia, conveniens, and consensus. In the treatise On Fate, this diversity of terminology disappeared, and Cicero began to use the Latin word contagio to translate $\sigma \nu \mu \pi \dot{q} 9 \varepsilon ı$. Moreover, only once did he use a direct transliteration of the Greek in that work (Cic. Div. 2, 69, 143).

\section{Sympathy in the treatise On Fate}

The diversity of terminology discussed above indicates that, from the beginning of this endeavour, Cicero had trouble translating the term sympathy using a single Latin term. Only in the last treatise did he find an appropriate equivalent, although it is unclear why he chose the term contagio to refer to Stoic sympathy in the treatise On Fate. As discussed above, in previous treatises, he used various expressions, and he seemed not to prefer the term contagio, using it only once prior to On Fate (Cic. Div. 2, 14, 33). The meaning of the prefix con-is defined above, while the verb tango primarily has the sense of "to make or come into physical contact with". ${ }^{22}$ Cicero almost certainly chose this word intentionally to emphasise the physical dimension of the Stoic term $\sigma u \mu \pi \dot{q} \vartheta \varepsilon \varepsilon$. In

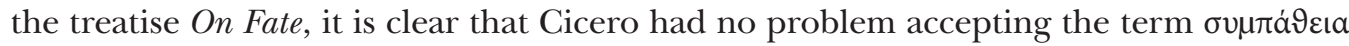
in the scientific sense, but he seemed to have a problem when the word was connected with fate or divination.

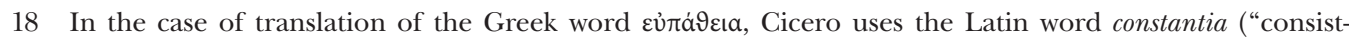
ency"), which has positive connotations (Cic. Tusc. 4, 5,10-6,14). See Graver (2002: pp. 134-138).

19 Liddell \& Scott \& Jones (1996: p. 1361).

20 For more on Stoic ethics, see Schofield (2003: pp. 233-256).

21 Glare (1968: p. 1361).

22 Glare (1968: p. 1904). 
In the treatise On Fate, Cicero discussed the possible influence of sympathy on two types of event. The first could be categorised as "empirical phenomena", in which the physical actions of sympathy are manifested. As an example of this, Cicero mentioned the poet Antipater, who suffered a febrile seizure on the day of his birth and who in old age died on his birthday of the same affliction. ${ }^{23}$ As another example, Cicero suggested the magical effect of the winter solstice. ${ }^{24}$ His third example discussed an anecdote about brothers who were both sick at the same time, ${ }^{25}$ while his fourth and final example concerned the diagnosis of certain illnesses based on colour changes in the urine or nails. ${ }^{26}$

All of these examples proposed that different types of occurrence are nonetheless physically connected: fever $\rightarrow$ birth and death, winter solstice $\rightarrow$ growth of the liver, two brothers $\rightarrow$ concomitant disease, and colour change in the urine or nails $\rightarrow$ illness. In the case of related phenomena of this kind, Cicero is willing to accept that sympathy has an effect (naturae contagio valet, quam ego non tollo). On the other hand, he asserts that the "influence of fate" (vis [...] fatalis) cannot be involved (Cic. Fat. 3, 5). ${ }^{27}$

Cicero illustrated the second category of events affected by sympathy using four examples that could be characterised as divination rather than empirical experience, although he provided examples that contained a certain dose of irony. The first example referred to a prophecy predicting that "a certain sailor without a name must perish in water" (illum sine nomine [...] in aqua esse pereundum). The oracles prediction was fulfilled when the "(sailor) without a name fell into a stream" (illum sine nomine in rivo esse lapsum). Cicero then clarified that this was a story about "a shipwrecked (sailor)" (naufragus) (Cic. Fat. 3, 5). ${ }^{28}$

The second example concerned the robber Icadius, who died after "a rock fell on his legs from the roof of a cave" (ex spelunca saxum in crura eius incidisse) (Cic. Fat. 3, 5). ${ }^{29}$ Adrianus Turnebus, who wrote a commentary on the treatise On Fate in the $16^{\text {th }}$ century, asserted that the rock fell on Icadius' leg because he had led a nautical life. ${ }^{30}$ Sextus Pompeius Festus also wrote that Icadius was a pirate. ${ }^{31}$ Based on these testimonies, S. J. Harrison concluded that Cicero intended to compare Icadius' death to the Roman

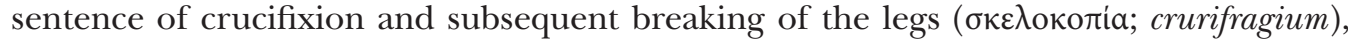
which was often used to execute pirates. The irony of the anecdote is that Icadius was

23 Plin. 7, 172; Val. Max. 1, 8 ext. 16. See Schallenberg (2008: p. 101).

24 The winter solstice (brumalis dies) was regarded as a magical date, when mice's liver grew, mint began to bloom, and seeds in apples turned to the other side (Cic. Div. 2, 14, 33). See Schallenberg (2008: p. 101).

25 Apparently, Hippocrates investigated the health of two twin brothers, who both fell ill at the same time and whose health improved and worsened in tandem (Avg. Civ. 5, 2). See Schallenberg (2008: p. 101).

26 For example, pale nails and fingers indicated death (Cels. 2, 6; Plin. 28, 68-69). See Schallenberg (2008: p. 101).

27 Transl. Sharples (1991: p. 59).

28 Ibid.

29 Ibid.

30 In eius crura ex spelunca saxum incidit, cum tamen vitam maritimam coleret. Cicero, ed. Bayer (2000: p. 114).

31 Rhondes Icadionque cum dixit Lucilius, duo nomina piratarum posuit, tam infestum sibi corpus et valitudinem referens, quam illi essent saluti navigantium. Festus, ed. Lindsay (1997: p. 332). 
not sentenced to have his legs broken on a cross as a convicted pirate, but instead died after a loose rock in a cave broke his legs. ${ }^{32}$

In both examples, the irony functioned on the level of subverted expectations based on the characters' professions. Both the sailor without a name (1) and Icadius (2) were professionally linked to the sea, but the manners of their deaths were not typical of their vocations, namely drowning in the sea and breaking of the legs, respectively. Instead, their lives ended in totally ironic circumstances - drowning in a stream and breaking of the legs under a fallen rock.

In the other two examples, the irony again revolved around death, but this time comprised subversions of meaning. The third anecdote told the story of the sophist and grammarian Daphitas, who asked the Delphic oracle for advice in the search for his lost horse. However, Daphitas' true motive was not to find a horse - he did not even own one. Instead, he wished to ridicule the infallibility of the oracle. Pythia predicted that he would find the lost horse, but that it would subsequently cause his death. As he was returning from the oracle, he boasted to all passers-by about how easily he had fooled the oracle. However, when Daphitas arrived in Asia Minor, he was caught by King Attalus, who commanded that Daphitas be thrown from a high crag that was known as "the

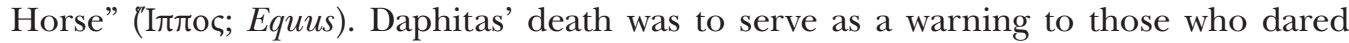
ridicule the gods. ${ }^{33}$ In the text, Cicero asked whether a prophecy that originally predicted a fatal fall from a horse (ex equo cadere atque ita perire) could be causally related to a completely different event in which the name "the Horse" referred to something else (nomen habebat alienum) (Cic. Fat. 3, 5). ${ }^{34}$

Cicero took a similar approach in his fourth and final example. He refused to believe an absurd story about King Philip, who was instructed in one prophecy to avoid "fourhorse chariots" (äpua; quadrigae) (Cic. Fat. 3, 5) and so commanded that all chariots be confiscated and brought to a place in Boeotia called Quadriga, which he also avoided. Despite these efforts, fate caught up with him, because the king's murderer Pausanius had a sword with a four-horse chariot depicted in a small image on the hilt. ${ }^{35}$

Unlike the previous category of events (fever $\rightarrow$ birth and death; winter solstice $\rightarrow$ growth of the liver; two brothers $\rightarrow$ concomitant disease; colour change in the urine and nails $\rightarrow$ illness), which were related to "nature" (natura), the latter four examples given above discuss "divination" (divinatio). In these cases, Cicero did not recognise the influence of sympathy. In his view, $\sigma \nu \mu \pi \alpha \dot{q} \varepsilon \varepsilon \alpha$ could only be ascribed when individual events, such as in the first group of examples, were directly related to "nature" (natura). In this way, Cicero emphasised the scientific character of the term, to use modern parlance, whereby fate in the sense of some higher entity has no room to exist. However, if the two occurrences were not connected by any scientific principle, such as in the second category of examples above, Cicero explained the connection between the occurrences by

32 Harrison (1983: p. 454); Schallenberg (2008: p. 102).

33 For more on the story of Daphitas, see Val. Max. 1, 8 ext. 8; Hsch. Mil. Onom. 14 (4. 160 M); Suid. $\Delta$ 99; Str. 14, 1, 39; Fontenrose (1960: pp. 83-84); Schallenberg (2008: pp. 102-103).

34 Transl. Sharples (1991: p. 59).

35 Ibid. For the story of king Philip, see Val. Max. 1, 8 ext. 9; Schallenberg (2008: p. 103); Habaj (2018: p. 34). 
appealing to "chance" (fortuna). By drawing this distinction, Cicero outlined sympathy's sphere of influence without completely rejecting the concept. In this regard, Magnus Schallenberg stated that Cicero could "have accepted that sympathy acted between the moon and the tide, but not between the flight of a bird and the start of a war" ${ }^{36}$

In this way, the Roman philosopher sees a fundamental difference between sympathy as divina ratio and sympathy as contagio naturae (see Cic. Nat. deor. 3, 11, 28; Div. 2, 60, 124). ${ }^{37}$ "The order of all things" (ratio omnium rerum $=\sigma 0 \mu \pi \dot{\theta} 9 \varepsilon ı$ in a very general sense) relies exclusively on "nature or chance" (ad naturam fortunamve) (Cic. Fat. 3, 6). If we grant that causal relations can be based on both of these principles, we avoid several problems related to the use of sympathy in the sphere of fate and divination.

It seems that Cicero gradually formulated his conception of the term sympathy as an acceptable scientific word and it was not until he wrote On Fate that he translated the word consistently. In that work, the author uses the word contagio exclusively. Since the verb tango implies "to make or come into physical contact with", Cicero was intentionally nudging the meaning of the word into the world of natural science, where he was willing to accept that the concept had somewhat of an influence. By choosing this translation and by refusing to accept the use of the word sympathy in the context of divination, Cicero was emphasising his own sceptical philosophical convictions, by which he was convinced that divination was only connected by chance to its supposed fulfilments.

\section{Bibliography}

\section{Primary Sources}

Arnim, I. von (Coll.). (1964). Stoicorum veterum fragmenta (Vol. I.-IV.). Stutgardiae: In aedibus B. G. Teubneri.

Bayer, K. (Ed. \& Transl.). (2000). Cicero: Über das Schicksal. De fato. Düsseldorf - Zürich: Artemis $\&$ Winkler.

Falconer, W. A. (Transl.). (1923). Cicero: On Old Age. On Friendship. On Divination. Cambridge, MA: Harvard University Press.

Graver, M. (Ed. \& Transl.). (2002). Cicero on the Emotions: Tusculan Disputations 3 and 4. Chicago London: The University of Chicago Press.

King, J. E. (Transl.). (1927). Cicero: Tusculan Disputations. Cambridge, MA: Harvard University Press.

Lindsay, W. M. (Ed.). (1997). Festus: De verborum significatu quae supersunt cum Pauli epitome. Stuttgart - Leipzig: B. G. Teubner.

Rackham, H. (Transl.). (1933). Cicero: On the Nature of the Gods. Academics. Cambridge, MA: Harvard University Press.

Sharples, R. W. (Ed. \& Transl.). (1991). Cicero: On Fate (De fato). Warminster: Aris \& Phillips Ltd.

36 See Schallenberg (2008: p. 104).

37 Szekeres (1991: p. 60). 


\section{Secondary Sources}

Baltussen, H. (2011). Cicero's Translation of Greek Philosophy: Personal Mission or Public Service? In S. McElduff, \& E. Sciarinno (Eds.), Complicating the History of Western Translation. The Ancient Mediterranean in Perspective (pp. 37-48). London: Routledge.

Brouwer, R. (2015). Stoic Sympathy. In E. Schliesser (Ed.), Sympathy: A History (pp. 15-35). Oxford: Oxford University Press.

Fontenrose, J. (1960). The Crucified Daphidas. Transactions and Proceedings of the American Philological Association, 91, 83-99.

Garani, M. (2007). Empedocles Redivivus: Poetry and Analogy in Lucretius. New York - London: Routledge.

Glare, P. G. W. (Ed.). (1968). Oxford Latin Dictionary. Oxford: Clarendon Press.

Glucker, J. (2012). Cicero's Remarks on Translating Philosophical Terms - Some General Problems. In J. Glucker, \& Ch. Burnett (Eds.), Greek into Latin from Antiquity until the Nineteenth Century (pp. 37-96). London: Warburg Institute.

Gregory, J. (1991). Cicero and Plato on Democracy: a Translation and its Source. Latomus, T. 50, Fasc. 3, 639-644.

Habaj, M. (2018). Dedičstvo po Filipovi. In Idem, \& F. Hř́bal, Alexander Vel’ký (pp. 11-41). Bratislava: Perfekt.

Hankinson, R. J. (1988). Stoicism, Science and Divination. Apeiron: A Journal for Ancient Philosophy and Science, 21(2), 123-160.

Harrison, H. J. (1983). Cicero and 'Crurifragium'. The Classical Quarterly, 33(2), 453-455.

Hartung, H. J. (1970). Ciceros Methode bei der Übersetzung griechischer philosophischer Termini. Diss. Hamburg.

Holmes, B. (2012). Sympathy between Hippocrates and Galen: The Case of Galen's Commentary on Hippocrates' 'Epidemics', Book Two. In P. E. Pormann (Ed.), Epidemics in Context. Greek Commentaries on Hippocrates in the Arabic Tradition (pp. 49-70). Berlin: De Gruyter.

Holmes, B. (2014). Proto-Sympathy in the Hippocratic Corpus. In J. Jouanna, \& M. Zink (Eds.), Hippocrate et les hippocratismes: médecine, religion, société (pp. 123-138). Paris: Académie des Inscriptions et Belles-Lettres.

Kalaš, A., \& Škvrnda, F. (2018a). Od Zoroastra k Sókratovi: vzţah antickej filozofie a mágie v 5. a 4. storočí pred Kr. (I). Filozofia, 73(2), 85-96.

Kalaš, A., \& Škvrnda, F. (2018b). Od Zoroastra k Sókratovi: vzt̉ah antickej filozofie a mágie v 5. a 4. storočí pred Kr. (II). Filozofia, 73(3), 212-223.

Karfík, F. (1998). Tò દ̇ $\varphi^{\prime}$ ๆ $\mu \tilde{v} v$ mezi Aristotelem a stoiky. Auriga, 35(1-2), 49-63.

Liddell, H. G., Scott, R., \& Jones, H. S. (1996). A Greek-English Lexicon. Oxford: Clarendon Press.

Long, A. A. (2006). From Epicurus to Epictetus. Studies in Hellenistic and Roman Philosophy. Oxford: Oxford University Press.

Powell, J. (2002). Cicero's Translations from Greek. In J. Powell (Ed.), Cicero the Philosopher (pp. 273-300). Oxford: Clarendon Press.

Schallenberg, M. (2008). Freiheit und Determinismus. Ein philosophischer Kommentar zu Ciceros Schrift De fato. Berlin - New York: Walter de Gruyter. 
Schofield, M. (2003). Stoic Ethics. In B. Inwood (Ed.), The Cambridge Companion to the Stoics (pp. 233-256). Cambridge: Cambridge University Press.

Sedley, D. (2004). Lucretius and the Transformation of Greek Wisdom. Cambridge: Cambridge University Press.

Sellars, J. (2006). Stoicism. Berkeley - Los Angeles: University of California Press.

Sorabji, R. (1983). Time, Creation and the Continuum. London: Duckworth.

Szekeres, C. (1991). Contagio und vis fatalis. Einige Bemerkungen zu Ciceros de fato. Acta Classica Universitatis Scientiarum Debreceniensis, 26, 57-61.

White, M. J. (2003). Stoic Natural Philosophy (Physics and Cosmology). In B. Inwood (Ed.), The Cambridge Companion to the Stoics (pp. 124-152). Cambridge: Cambridge University Press.

Mgr. Peter Fraňo, PhD. / peter.frano@ucm.sk

Department of Philosophy and Applied Philosophy

University of Ss. Cyril and Methodius in Trnava, Faculty of Arts

Námestie J. Herdu 2, 91701 Trnava, Slovak Republic 
